Disinfection by Formaldehyd.

Iowa City, Iowa, July 20, 1906.

To the Editor - A note in The Jocrnal, July 14 , in the de partment of Miscellany, states that in using the potassium permanganate method of liberating formaldehyd gas the amounts used are $3 \frac{1}{2}$ ounces of potassium permanganate and l pint of 40 per cent. solution of formaldehyd to every 1.000 cubic feet of air space to be disinfected. During the past two years I have experimentes a great deal with this and other methods of generating formaldehyd gas in the Iowa State Board of Health bacteriologic laboratory and in buildings of all kinds to test thoroughly the various methods. I consider the potassium permanganate method of liberating gas as the hest. Realizing that it will no doubt be adopted more and more by the physicians of the country, I can not forbear making a correction in the article above referred to.

It is impossible to evaporate a pint of the 40 per cent. solution of formaldehyd with $3 \frac{1}{2}$ ounces of potassium permanganate. To do so it will require from 6 to $61 / 2$ ounces, and with the use of any less the disinfection, I am sure, will not be satisfactory. The article states that the Maine Board of Health recommends $61 \%$ ounces of potassium permanganate and 2 pints of formaldehyd solution for every 1,000 cubic feet. This is an error. They recommend 13 ounces of the permanganate, according to their recent bulletin on the subject. It should alwars be borne in mind when using this method that a part of the formaldehyd is changed to formic acid during the process of evaporation. We should use, therefore, correspondingly more of the formaldehyd solution than when employing other methods. For that reason I always recommend that 20 ounces of 40 per cent. formaldehyd solution and $81 / 2$ ounces of potassium permanganate be used for every 1,000 cubic feet of room space to be disinfected. I have also found that by first heating the vessel in which the disinfectant agents are placed the evaporation will be more complete. I consider it. therefore, a desirable part of the process.

Henry AtbFrt.

\section{The Retirement of Professor Austin Flint.}

New York Citry, July 17, 1906.

T'o the Editor:-Cornell University Medical College has suffered a serious loss in the retirement this year of its distinguished professor of physiology, Dr. Austin Flint. The many practitioners who, in their student days, came under his instruction in the former Bellevue Hospital Medical College, and later in Cornell, should be interested in this brief note of farewell.

A man who, up to the present time, has been a vigorous and effective teacher, and who, in his seventieth year, has issued a new edition of his work on physiology, revised and in every respect up to date, must be intellectually still in his prime. The university, having fixed an age limit to the employment of its instructors, was unable longer to reap the advantages of Dr. Flint's services. The loss will fall heavily on the present and future students, for as a teacher the retiring professor has had no superior in the history of American medical education. No one who ever attended his lectures could remain ignorant of the principles of physiology, which - he taught not as a mere theory, but as directly related to medical practice. He taught it with a clearness, a thoroughness, and an emphasis that made an indelible impression on those who heard him. This clearness and force of statement were supplemented by a dexterity in demonstration which made his teaching doubly interesting and effective. There have been great lecturers who failed in their experiments, and great experimenters with no talent of expression. Dr. Flint's experiments have been the counterpart of his discipline, exact, lucid, and illuminating. He was never at loss for a word, and his laboratory technic was almost faultless.

This efficiency in the class-room was not merely the aptness to teach of a clever pedagogue. Dr. Flint's skill as an instructor was the result of a perfect mastery of his science, of a facility of speech due to rhetorical instinct and wide reading. As an author Dr. Flint is even more admirable than as a teacher. His work on physiology has become a great scientific classic. Its literary style is without either the pedantry or the vulgarity which mars the works of some of our ablest medical writers. It is a prose style, which, from its simplicity and elegance, will always be classical, yet always modern. To the scientific resources of the author the book bears emphatic witness. Dr. Flint's original work in his department has been manifested in a variety of ways. Not only has he contributed largely to our knowledge of the processes of digestion, secretion and circulation; he is also to be numbered among the ablest neurologists and alienists of our time. For, in addition to his knowledge of cerebral physiology and pathology, his native good sense and his experience as a man of the world have given him prestige in that difficult and delicate department of medical science and practice. As an expert in mental diseases he has always shown himself to be not merely a competent alienist, but an honest man.

About three years ago he collected and published in two large volumes more than sixty essays and articles contributed by him at various times to medical and other periodicals. These show at how many points their author has touched life. Besides the contributions to the literature of his own particular Fach, there are papers which relate to many other widely different subjects-historical, medicolegal, diagnostic, therapeutic and dietetic. There are reports on hospitals and other charitable institutions. There are discussions concerning gymnastics, medigal ethics, pedagogics, and the practical life of the medical student. All these topics are handled with literary skill, and would of themselves be a lasting memorial of a life devoted to science and letters. The maxim that no evil should be spoken of the dead is sometimes interpreted to mean that there should be no praise of the living. Nothing need here be said of those personal qualities which have re. inforced Dr. Flint's scientific attainments and influence. As a controversialist he has frequently aroused bitter antagonism. But his most decided opponents would admit that he has been a fair fighter, and that his manner of warfare has been that of a man, not of a serpent. It is simple justice to say that Dr. Flint has left a permanent impression on the medical institutions of the city, first as dean of the Bellevue Hospital Medical College, and later as one of those who have directed the medical department of Cornell. His example should be of advantage to the new generation of physicians and surgeons, for he has shown how a great specialist and man of science can be efficient in matters of practical importance, and how the genius and virtuosity of a learned physiologist may be combined with the rare distinction of a man of letters.

Samuel Alexander.

\section{Triplets Living at Forty-seven Years of Age.}

Cincinnati, July 16, 1906.

To the Editor:-I know of a remarkable case of triplets, born March 24, 1859, living at this time, now 47 years of age, two brothers and a sister. One of the brothers has been a life insurance agent for twenty years, and I know him intimately; all are living in good health. As far as my knowledge goes this record is unequaled. JoHN L. Davis, M.D.

\section{"Delicensed" Physician.}

Chicago, July 17, 1906.

T'o the Editor:-In a magazine article, having occasion to use an adjective descriptive of a physician with license revoked, I coined "delicensed physician." This term has met. no serious objections from the medical profession (I am a practicing lawyer) and as the authorities contain no explicit term for that purpose, I suggest this word. I tried to write this grouping in a sentence, "disbarred lawyer, delicensed physician, suspended clergyman." The sentence is far from pleasing when "physician with license revoked," is used in connection with suspended or expelled clergyman and disbarred lawver. 